\title{
THE MESSAGE, SOCIOCULTURAL BACKGROUND, AND POLITICS OF THE RELIGIOUS ISLAMIC SERMONS IN THE NETHERLANDS
}

\author{
Rr. Suhartini \\ Sunan Ampel State Islamic University Surabaya, Indonesia \\ E-mail: suhartini@uinsby.ac.id
}

\begin{abstract}
Da'wa is not merely concerned with theology and religion but also addresses the socio-political aspects. These aspects are highly dependent on the background of the dai or preacher and the public space of politics in the religion which conveys the da'wa message. Using a qualitative method, this research focuses on three questions, which are the priority of the da'wa message, and the suitability of the da' $i$ qualification in the contemporary Netherlands. The third question entails how the politics of religion support the life of Muslim migrants, and for this issue, some mosques and Muslim communities were chosen for data collection. Subsequently, this research showed that the most delivered topics of da'wa message were about aqidah or creed, shari'ah, which is the Islamic law, and then akblaq or ethics. Also, the background of the da' $i$ heavily influenced the selection of the da'wa material and involved two major streams, which were Salafi and Sunni. The da'wa activity by the Sunni da' is tended to be more open, compared to Salafi activities. Concerning this religion's politics, the Dutch government launched a program, which involved the Pillarization of Islam. The program was to enable the government to maintain control over the activities of Muslim migrants and was also for the benefit of the multi-origin and multi-ethnic ones. However, this measure proved to be ineffective, and da'wa has continued without following this pillarization program, as being a Muslim is a result of personal will, and not just because of a sermon.
\end{abstract}

Keywords: Islamic Sermon, Culture of Social Origin, Political Religion, Muslim migrants, the Netherlands. 


\section{Introduction}

Amidst the significant development of da'wa in the Netherlands, proximity becomes basic problem in the activities of the da'is (preachers). This article examines da'wa activity among Muslim minority in the Netherlands by considering the religious background of $d a i$ or imam, as well as political context in the Netherlands especially concerning religious policy in public space. Religious messages delivered in the Netherlands are usually conveyed in the vernacular language of the dai or imam. The dais of imams are usually trained in their countries of origin. Therefore this fact is thought to influence material and selection of the delivery of religious message. The religious message usually delivered concerns ethic and conducted with less emphasis on social issues. This last part is due to the policy of the Dutch government on the expression of religion in public space, with the issue of cultural integration into European culture and community as the major issue faced by Muslim migrants in Europe.

Although the Netherlands is often seen as the most secular country in Europe, religion and faith-based organizations have long been embedded in the culture and structure of society. ${ }^{1}$ Many different religions and beliefs entered by immigrants developed into this country. Moreover, Islam comes to the Netherlands brought by migrant workers, especially from Turkey and Morocco, as well as the return of the Indonesian-origin Surinam people to the Netherlands. ${ }^{2}$

According to FORUM (Institute for Multicultural Affairs), in 2010, almost $60-70 \%$ of Islamic religious ummah of Moroccans and Turks claimed to feel at home in the Netherlands. ${ }^{3}$ Migrant workers generally have a low level of education. Their number is about 1,5 million or $5.8 \%$ of Dutch population. They often appear in the media for about $63 \%$ concerning negative behavior, which also means bad image for Muslims. Elsewhere in Europe, Islam is often considered as

\footnotetext{
1 Justin Beaumont, "Candice Dias, Faith-Based Organisations and Urban Social Justice in The Netherlands", The Royal Dutch Geographical Society, KNAG, Vol. 99, No. 4 (2007), 382-392.

2 Semiha Sözeri, Hülya Kosar Altinyelken, Monique Volman, "Training Imams in the Netherlands: The Failure of a Post-secular Endeavour," British Journal of Religious Education (June 2018).

${ }^{3}$ FORUM, The Position of Muslim in the Netherlands (Utrecht: Postbus, 2010), 28.
} 
alien culture which disturbs the life of English normal life. ${ }^{4}$ Islam is news in Europe for three reasons, religion, education, and fundamentalism. ${ }^{5}$ If it is viewed from the context of da'wa, which is a coordinated effort to strengthen Islamic belief among Muslims and in practice is unconvinced by association movement or available institution, then this is a disadvantageous situation as well as a challenge for Islam (Muslims). ${ }^{6}$

From the theoretical perspective of sociological explanation, this article focuses on the examination of da'wa message as described in da'wa syllabi in mosques and Muslim community and relates them with the culture of social origin of the da'wah actors. The mosque was chosen as the focus of this study because of the essential place of the Muslim public presence in the Netherlands, particularly the center of Islamic sermon in the Netherlands. ${ }^{7}$ Further, this article will examine priority scale of da'wa role in relation to politics of religious space in the Netherlands.

This article begins with a discussion on the da'wa material in the Netherlands. Later, it will dwell with the description of da'wa material in mosques in the Netherlands. I will also study the relation between material or topic selection of da'wa and the cultural background of the dais. Finally, it will discuss the relationship between the Dutch policy on religion in public space with the selection of da'wa topics.

\section{Islamic Sermon}

In addition to Jum'ah (congregational) sermon, Muslim preachers also deliver their lectures in scheduled religious lessons in mosques after hours (after maghrib and isha prayers). Materials of the lessons usually are current affairs, such as commemoration of the prophet's birth (mawlid), Rajab celebration, Ramadan month, commemoration the revelation of the Quran (nuzulu al-Qur'an), and so

\footnotetext{
4 John Richardson, Representing Islam: The Racism and Rethoric of British Broadsheet Newspaper (Amsterdam: John Benjamins Publishing Company, 2004).

5 Elisabeth Poole, Reporting Islam: The Media and Representation of Muslim in Britain (London: I.B. Tauris, 2002).

${ }^{6}$ Johan Meuleman, "Da'wa", Competition for Authority, and Development, Journal Bijdragen Tot De Taal-, Land-En Volkenkunde, Vol. 167, No. 2/3 (2011), 236-269.

7 Oskar Verkaaik and Pooyan Tamimi Arab, "Managing Mosques in the Netherlands Constitutional versus Culturalist Secularism", Journal of Muslims in Europe, Vol. 5 (2016), 251-268.
} 
forth. Alternatively, some current debatable issues are also discussed, such as veiling (bijäb). Those materials are discussed in the light of three elements of Islamic teaching, creed (aqidah), Islamic law $\left(s_{a r}{ }^{-} a b\right)$, and ethic (akbläq). The three elements are often related to important concepts in Islam. Iman is related to 'aqidah, Islam is related to shari ${ }^{-} a h$, and ihssan is related to akbläq. ${ }^{8}$

The first and most fundamental theme, aqidah, consists of the commitment of Muslims to obey beyond any doubt towards the will of God. This covers six basic covenants; the belief that there is no god but Allah, (2) belief in the existence of supernatural beings such as the angel's God, (3) belief in the messengers of God, (4) belief in the holy books that were revealed to the messengers, (5) belief in the hereafter, including accountability of deeds with rewards (heaven) and punishment (hell), (6) belief that there is definite rule of God which govern this life. This conviction is stated in the Quran, namely Chapter 2, verses 2-4 and 177.

Second theme, Shari' ah covers religious regulation as revealed in the Quran and exemplified by the Prophet. The coverage of Shariah includes rituals (ibadab) and human interaction (mu'amalab) as it is usually categorized by Muslim jurists. Ibadah includes five daily prayers, Ramadan fasting, zakat alms, and hajj pilgrimage. Whereas mu'amalah includes property exchanges (buying, selling, leasing, and labor), marriage, inheritance, social contract (such as public consultation), and so on.

The third theme is akblaq (ethic and morality). It drives Muslims to do their best without any supervision because they believe that God is all-knowing and watching. Morality in its usage in the Quran can be defined as an act or a deed that evolves into habit. Therefore, a man may develop al-akbläq al-karimah (good attitude) or al-akbläq almadhmümah (bad behavior). Meanwhile, Ahmad Amin defines morality as a repeated act that it was easily done without any further thought. Concerning relationship with others, morality can be defined as an attitude and behavior that totally respect others' existence.

In the case of da'wa in the Netherlands, especially by referring to some mosques and religious lessons of the Dutch Muslim community, the materials of $\mathrm{da}^{\text {'wwa }}$ are far from uniform. The materials send by mosques to their congregations are in the form of

8 Moh. Ali Aziz, Ilmu Dakwah (Jakarta: Pranada Media, 2016); Wahyu Ilaihi, Komunikasi Dakwah (Bandung: Rosdakarya, 2010). 
sermons, lectures, and individual consultations. Written materials are spread regularly through books and internet website. Generally, da'wah materials of mosques and Muslim community in the Netherlands cover three elements of Islamic teachings; aqidah, shari'ah, and akblāq. They originate from 17 mosques and Muslim communities in three cities, namely Leiden, Amsterdam, and Rotterdam.

The most materials that are sent to Muslim community in the Netherlands are a matter aqidah and shari'ah. Of the two topics, shari' $a b$ theme is used regularly as reading material or written ones in every meeting or da'wa function. In addition, although aqidah theme is often discussed, its discussion is less intensive. The least discussed theme is akblaqq, which is quite normal, because this theme is crisscrossing with the mu'amalab sub-theme of shari'ah. Still, the authentic category of moral tolerance and religion in the context of contemporary Sufism is discussed albeit sparingly.

Reading material on aqidab found in al-Ikhlas Indonesia mosque dominates the shelves of the mosque. In a religious event celebrating the Islamic new year in Muharram month, the mosques in collaboration with PPME (Persatuan Pelajar Muslim Se-Eropa; all European Muslim students association) invited religious scholars of Nahdlatul Ulama, Dr. Ir. Wahfiuddin to deliver a lecture. He chose to speak about belief, the existence of rüh (spirit), and life after death. In addition, he also explained the difference between "passing away" and "death" in spiritual journey to Barzah (transition) realm based on the interpretation of the Quran chapter al-An'ām verse 60. Furthermore, preachers attending the event advised the audience how to prepare life after death and performed prayers for the deceased with supplication. Visit the graveyard was also part of the lecture to defend from the opposite opinion held by the Salafis, who denies the value of prayers for the deceased.

In addition, concerning the writing for da'wa purposes, aqidah material can be accessed through periodic booklet distributer in mosques or through short posting in official website of the mosques. A booklet that attracts wide interest of the congregation in Mimar Sinan Camii Mosque is a booklet entitled Islam written by Dr. Fahri Demir published by Hollanda Diyanet Vakfi Yayinlarui, a Turkish foundation. This booklet discusses aqidah theme intensively.

${ }_{9}$ An interview with Imam Hasanath on October 4th 2015 , at Roterdam. 
As a system of belief and the way of thinking for Muslims about God, aqidah is an important theme so that it is frequently delivered by preachers. It is mainly because of worry among preachers and Muslim leaders that there would be misunderstanding about and erosion of basic conviction of Muslims in the Netherlands. As a result, da'wa materials on aqidah are sent to Muslim communities. For instance, in the al-Sunnah mosque of The Hague, which is affiliated to the Salafi community, there is regular recitation of aqidab theme by discussing a book entitled Usül al-Sunnah written by Aḥmad b. Hanbal. The religious study is conducted after maghrib prayers. According to its congregation, the fundamentals of the Sunnah should be emulated as identical as those practiced by the companions of the prophet. Thus, Muslims should avoid any innovations, since it is considered unorthodox. This book describes every category of Sunnah, which Muslims should believe and practice. Anyone who ignored one of these Sunnah will not be considered as the Ahl al-Sunnah (people of Sunnah).

Here, Sunnah includes: the belief in good and bad destiny; the Quran as the verbatim words of God, not creature, eye witnessing God in the hereafter as narrated from the authentic hadith of the Prophet Muhammad; belief in the scale of deeds in the hereafter; belief in the torture after death ('adhäb al-qubr), the uninterrupted obligation of jihad until the hereafter; thus, jihad should not be abandoned.

Meanwhile, Imam Malik mosque in Leiden conducts regular aqidah classes for the youth. This includes a program named Youth Education under guidance of Sheikh Said el Mokadmi delivered in Dutch language. Unlike other free of charge programs, participants of this class must pay sum of money. Similarly, the Euromoslim mosque in Amsterdam conducts weekly lesson attended by Indonesian-origin Muslims. There is no fee for attending the classes, though. The aqidah theme discussed in the classes includes: (1) Tawhid al-Asmä, the oneness of God in His characteristics and names; (2) Tawhid alRubuibiyah, the oneness of God in His Majesty. He creates, sustains, governs, provides, and controls His creatures; and (3) Tawhid alUlübiyah, oneness in worshipping God. It means that all creatures, including human beings, angel worship only God Almighty.

Da'wa materials on aqidah are discussed comprehensively in lectures or written in official website of the mosque. In this aspect, 
the ulama and preachers are very proactive in spreading da'wa materials on aqidah. Nevertheless, aqidah theme is also requested by Dutch people who are not Muslims, not initiative of the mosque management. Almost all mosques in the Netherlands are regularly visited by non-Muslims who want to know more about Islam from the insider perspective. Too, some newly converts usually need an intensive and individual discussion about aqidah with several Muslim scholars in mosques.

For instance, in Suleymaniye mosque in Tilburg, two to three Dutch people converted to Islam every month. As told by Suleyman Balkaya from management of the mosque, the conversion is a result of regular discussion between Muslims who run the mosque with the Dutch who visit the mosque. He says: "They visit the mosque because they are interested to know more about Islam, some of whom also come to consult their private and family issues. From then, they eventually converted to Islam". ${ }^{10}$

Conversion to Islam happens to other mosques across the Netherlands, namely al-Ikhlas mosque, which its congregation is Indonesian Muslims. The interest of the Dutch to Islam is due to Indonesian Muslim tradition that emphasizes social interaction, which is barely existent in Dutch culture. In addition, al-Ikhlas mosque shows its traditional character of Nahdlatul Ulama with its strong sense of togetherness among the congregation. In Ramadan month of 2015, when the fasting was very long (starting from 3 AM to $10 \mathrm{PM}$ ), numerous religious activities were conducted as demanded by the congregation, such as workshop for Muslim youths, reciting the supplication for the prophet (salawät), discussing contemporary Islamic jurisprudence (baḥth al-masäi), congregational prayers, recitation of the Quran, students presentation (namely the competition of recitation of the Quran), religious lectures, and breaking the fasting event. The harmony and cordiality shown by the congregation of al-Ikhlas mosque made the Dutch interested in this version of Indonesian Islam. The practice of mosque da'wa in Indonesia is inseparable from cultural aspect. This is the main feature of Indonesian style of da'wa.

10 An interview with Suleyman Balkayan on October 10 th 2015 at Tilburg Mosque. 


\section{Culture of Social Origin}

Some mosque which is affiliated to certain concepts must adjust their aqidah doctrine based on the sects of Islam. Sunni group of Indonesians, Moroccans, and Turkish belong to Ash'arī theology, while other sects like Shiites, Ahmadis, Salafis, and Qoranis have their own set of theology. ${ }^{11}$ Moreover, the type of Muslim's Netherlands so far meanly been active in mosques and the same of public sphere of religion. ${ }^{12}$

For instance, al-Ikhlas mosque in Amsterdam, which is dominated by Indonesians, conducted religious lectures about Aqidah on the sub-theme of Iman and Islam in end of time. The lecture covered topics of belief in death and how to deal with it and what after it, by performing dedicated supplication for the deceased (Tahlil, recitation of Yasin chapter of the Quran, istighathah, and so on). The selection of topics followed the agenda of Islamic calendar, in which Muslims would organize themselves to face the end of time. The management of al-Ikhlas mosque invited religious leaders and scholars from Indonesia to deliver lectures about the relevance of the Hijrah with the spirit of change in every Muslim group. In so doing, various issues were explained, including the importance of understanding of Islamic calendar in relation to death, which everyone would certainly experience. It also dealt with life after death, and preparation for this after death. ${ }^{13}$

Likewise, Ulu mosque in Utrecht region flocks its internet website regularly with themes of Tawhìd, Imàn, and Islam. The advice is that Muslims should believe in God, the Prophet, the Quran, divine destiny, angels, and end of time. In addition, it states that every Muslim must experience phases of Islamic syahädah (testimony), salat prayers, 'amal (good deed, usually associated with charity), and hajj pilgrimage (for those who can afford). All internet posts in Turkish mosques, which are Sunnite and its teaching, which is spread through their website, are so very basic that it is convenient to understand, even by beginners' standards.

11 Maykel Verkuyten and Ali Aslan Yildiz, "Muslim Immigrants and Religious Group Feelings: Self-identification and Attitudes among Sunni and Alevi TurkishDutch", Ethnic and Racial Studies, Vol. 32, No. 7 (2009), 1121-1142.

12 Jan Rath, Against the Current: The Establishment of Islam in the Netherlands (Canada: Canadian Diversite, 2005), 4.

13 An observation at al-Ikblas mosque, Amsterdam on October 9st 2015. 
On the other hand, mosques run by Salafi groups tend to emphasize on purification of Muslim belief and accuse all tradition and belief that was never taught or practiced by prophet as unorthodox. In the aqidah aspect, Salafi group seems to be quite "harsh" in responding to religious practices in other mosques that do not share Salafi opinions. The influence of this group increasingly significant because more mosques adopted Salafi ideology, like Saada mosque in Amsterdam. After attending Jum'ah congregational prayers, a new convert named Thoar Varenkamp shared his thought as follows:

...but seeing Saada Mosque in Amsterdam Amstelveen, I think it has been influenced by Salafi. The sermon spoke about commitment. Ashura celebration was discussed intensively. I assumed that it (Shiite) was another religious sect, but no need to be rude. For me, it is not interesting. If it was accused of being bid'ah (innovation), it was not part of aqidah. It (accusation) is not nice. The words (of the preacher) were very offensive."14

Similarly, El-Tauhid mosque in Amsterdam moves towards that Salafi direction. At the beginning of the Jum'ah congregational sermon on the $23^{\text {th }}$ of October 2015, the argument behind the prohibition of bid'ah was emphasized. The preacher began his reading by proposing arguments for abandoning bid'ah. The main issue of the sermon was encouragement for abandoning immoral behavior, such as lying, envy, adultery, hoax, and so on. The preacher related the prohibition of bid'ah to a hadith which was transmitted by Muslim ibn Hajjaj in his hadith collection number 867, in which the Prophet says: "truly, the best word is the Holy book and the best guide is the guide of Muhammad. The worst case is bid'ah. All bid'ah in religion is bad, and all bid'ab is astray. The preacher further combined this hadith with another hadith transmitted by al-Nasāâ in his hadīth collection number 1578 in which the Prophet says: "The place for digression is hell." Such hadiths are frequently used by Salafi preachers with offensive words in their sermon.

The topic of fiqh 'ibadah (ritual) discussed in mosques includes the virtue of prayers in congregation (salab al-jamáa $a b$ ) as it was delivered in Imam Mālik mosque in Leiden; the importance of ritual prayer or litany (dhikr) after five daily prayers which become main staple of all mosques for the purpose of remembering the hereafter

${ }^{14}$ An interview with Thoar Varenkamp on October 16 th 2015 at Amsterdam. 
and following the example of the Prophet Muhammad. It also practiced in Amsterdam Taibah Djama mosque. A similar practice that emphasizes daily ritual prayer is also found in Saada mosque in Amsterdam.

Another regular ritual theme is the guide to ritual prayer after five obligatory daily prayers. Almost all mosques, either those dominated by Moroccans, Turkish, or Indonesians, provide free of charge leaflets containing ritual prayer for their congregations. In fact, El-Tahweed mosque in Amsterdam El-Fath mosque in Maastricht put a big paper board in the wall containing the words of ritual prayers which are usually chanted after five daily prayers, whereas El-Fath mosque in Maastricht put the ritual prayers in its main prayer room so that the congregation may read it directly. The dhikr usually consists of Istighfär, Tablil, Tahmid, Takbir, Ayat al-Kursī, and short chapters of the Quran, namely al-Ikhlāṣ, al-'Alaq, and al-Nās. ${ }^{15}$

In addition, the theme of ritual about $d u^{\prime} a$ (supplication) is equipped with its practical aspect. Some mosques add materials about detailed procedure of ritual prayers, which start from activities before salat prayers up to small move and reading in the $d u^{\prime} a$. The website of al-Salam in Rotterdam also allocate time slot for discussing cleanness before salat prayers. The encouragement for doing istiyale (teeth cleaning using a twig) is also uploaded in the readers' column on the website.

Mosques in the Netherlands regularly provide reading materials concerning procedure of the reading in the salat prayers and its movement. The first 'real' mosque (with minarets) was built in the town of Almelo in $1975 .{ }^{16}$ Since $d u^{\prime} a$ is considered important in Islam, the topic of $d u^{\prime} a$ seems important so that it is delivered quite frequently. Some materials for $d u^{\prime} a$ are found in Mescidi-Aksa Camii (The Hague), di Mimar Sinan (Leiden), and Fatih Camii (Amsterdam). ${ }^{17}$

Further about the format of da'wah and religious writings on the procedure of salat prayers can be viewed from the website of Euromoslim mosque. It puts emphasis on the correct way of

15 An observation at El-Fath Moskee on October 21 ${ }^{\text {st }}$ 2015; an observation at ElTawheed Moskee on October 23rd 2015.

16 Thijl Sunier, "Moslims in Nederland, Nederlandse Moslims: Sociale Integratie in de Sfeer van Religie" in G. Engbersen and R. Gabriëls (eds.), Sferen Van Integratie. Naar Een Gedifferentieerd Allochtonenbeleid (Amsterdam: Boom, 1995).

17 Ibid. 
performing salat prayers. The mosque that is based in Indonesia is considered to have inclination to Salafi people because its $d u^{\prime} a$ guidance is from the hadith, "Du'a with the example of the Prophet's characteristics." Likewise, Euromoslim mosque and al-Sunnah mosque in The Hague have similar patterns in providing regular lessons concerning procedure of salat prayers that exemplified the practice of the prophet Muhammad.

Aside from Djame Taibah mosque, the official website of alSalam mosque provides sermon material about the virtue of reciting the Quran by explaining that the Quran is God's decision, source of knowledge, and guidance for true life. Therefore, the purpose of the sermon is to let Muslims reciting the Quran to remain close to God.

However, essentially the theme of ritual is not only about $d u^{\prime} a$, but also about the recitation of the Quran. The topics are sometimes about ritual in all spectrum; the confession of the faith, salat prayers, zakat alms, fasting, and haij pilgrimage to Mecca. These are addressed in the sermon of al-Salam mosque in Rotterdam.

The statements of $d a$ i (preachers) sometimes become dominant factors of consideration for those who want to convert to Islam. Although it might be discussed in a bigger forum, the topics concerning rituals are discussed in individual discussion or consultation between preacher and potential converts. Among the five pillars of Islam, salat prayers are the most discussed topic. Certainly, it is normal because preachers sometimes have their own choice of topic based on certain circumstances. In addition, salat prayers are always a trending topic because of its utmost importance and its daily occurrence, unlike the rest. Nonetheless, preachers choose topic of sermon also by considering the need of the congregation when they need information about their rituals.

Therefore, the consideration to choose the topic of sermon depends on a certain period of the rituals. For instance, when nearing the Month of Ramadan, the topic of sermon mostly about fasting. A similar statement also applies to zakat alms and hajj pilgrimage, which become a major topic during the zakat period and hajj season. Concerning hajj pilgrimage, Indonesian-origin Muslims expressed their inconvenience when they are grouped with pilgrims from different countries because of some technical issues. However, the waiting list for Indonesian pilgrims gets longer because of limited 
quota of the Netherlands. About this issue, Budi Santoso, a caretaker of al-Ikhlas mosque tells his story:

"We are planning to open travel agency that is dealing with hajj pilgrimage here (The Netherlands) because of promising market. There are many Indonesians who stay in this country. My experience when I made my pilgrimage with the pilgrims from Morocco was not a memorable one. They often quarreled for trivial issues, such as quarrel about the words of $d u^{\prime} a$, ritual prayers, procedure of ablution, and so forth. Many Moroccans are Salafis. During hajj pilgrimage, the Moroccans consider trivial things as big deal. They urge others who have different opinions (concerning rituals in haji) to form own group. If we have different opinions, we are requested to form small groups during hajj pilgrimage. Therefore, we, Indonesian people, want to establish own event organizers that will lead our brothers and sisters to hajj pilgrimage instead of becoming burden of other groups. I, (during last hajj season) stayed in the nearest hotel to the al-Haram mosque. My hotel door just across the tawaf area of the Haram mosque. Generally, the cost of hajj pilgrimage from the Netherlands is about 5000 Euros, with a five-star hotel along with the same building with a big group. With the location of hotel in Mecca, the pilgrims were not only Moroccans but also other nationalities from the Netherlands. Other convenient aspects (of having own group) concerning the waiting period. In the Netherlands, when Muslims wish to perform hajj pilgrimage, they do not have to wait for years. They can perform hajj pilgrimage in the same year they register, unlike in Indonesia". ${ }^{18}$

Concerning the cost of building a mosque, there is a unique phenomenon about zakat alms among Indonesian Muslim community. They allocate special funds for building a mosque from zakat alms. PPME referred to the opinion of a contemporary mufti Shaikh Yusuf al-Qardawi which states that mosque buildings in the Europe are categorized as fi sabil Allah (lit. "in the cause of God," which is usually related to jihad). Therefore, mosques can be funded by zakat alms. In addition, the experience of al-Ikhlas mosque in 2015 indicated that the fund from zakat alms was sufficient to fund mosque improvement. After a preacher encouraging the congregation to donate charity for the mosque, money poured into the mosque. The money was used to buy property and construct a building for

\footnotetext{
18 The interview result with Mr. Budi Santoso as senior official of Al Ikhlas mosque Amsterdam 18 October 2015.
} 
cultural purposes as well as daily activities of the mosque. The cost of improvement was $€ 495.000$. Before that, for its da'wa routine, the mosque rented a room in a school owned and run by Moroccans.

As previously mentioned, the theme of zakat alms in al-Ikhlas mosque coincides with the lecture on fasting, especially in Ramadan month. Whenever the Ramadan month comes, the theme of fasting dominates the lectures. Some mosques distribute leaflets containing fasting schedule (schedule for starting and breaking the fasting), tips of fasting for people with diabetes, and stories about the benefit of fasting. When Ramadan Month comes during summer, the fasting period will be much longer (about 14 hours). The eating period is only 5 hours or so. Concerning this, a student from Indonesia told a story:

"In Ramadan Month in the Netherlands and Europe, salat payers time is an interesting topic worthy of telling. For sure, the Turkish community has a different schedule of fasting from the Moroccans. Some Muslims start their fasting much later and, therefore, shorter time for fasting during summers. However, when the Ramadan Month coincides with January (winter season), the fasting starts at 6.40 AM and ends at 4.58 PM. Thus, fasting period is only about 10 hours. During Summers, fasting period is much longer, up to 17 hours. More unusual is that the time for $I s h \bar{a}$ ' (evening) prayers start after midnight (00.11 AM). Therefore, Muslims in the Netherlands do not sleep anymore after salat taräwĭh (Ramadan devotional prayers) until salat subh (dawn) prayers, which usually starts two hours after the finish of salat tarawih prayers. Some Muslims go for vacation out of Europe to avoid lengthy fasting period in the Netherlands". ${ }^{19}$

Similar to zakat alms and Ramadan fasting, hajj pilgrimage is another important topic among Muslims in the Netherlands, especially because Dutch government does not manage the hajj pilgrimage. As a result, some mosques and Muslim communities compete with each other to provide hajj pilgrimage plan. In addition to materials on hajj rituals, they also arrange functions and make arrangements for hajj pilgrimage groups to Mecca. Moroccan and Turkish Muslims are clever in seizing this business opportunity.

The cost of hajj in 2015 was reasonably profitable from a business perspective. For instance, the Diwan travel agent in Tilburg

19 Alif Magazine, "Menikmati Perbedaan: Shalat Jumat di Belanda (1)", 22 January 2015/accessed on October 23 2015 from http://alifmagz.com/?p=29842 
charged $€ 4150$, with the accommodation of a room in Mecca for four people) or $€ 5000$ (with the accommodation of a room in Mecca for four people) for pilgrim that departed from the Netherlands directly flew to Saudi Arabia. Truly, with such cost, facilities enjoyed by Indonesian Muslims are better than their Indonesian counterparts departing from Indonesia. In addition, Diwan Travel Agent also offered a more expensive hajj package. Its facilities included the fourstar hotel in Medina and the five-star hotel in Mecca. Considering that there are only a few hajj travel agents in the Netherlands, it is still a promising market, especially for Muslim migrant workers from Turkey and Morocco.

In addition to topics on five pillars of Islam, another renowned and reactive theme is the slaughter of cattle flock during id al-adha $\bar{a}$ period. This can be reflected from the lecture material in al-Hikmah mosque of The Hague, especially after the salat prayer of 'id al-adha $\overline{\text {. }}$. Likewise, the Ashura, an event to commemorate the death of Husayn b. 'Alī b. Abī Ṭâlib, the grandson of the Prophet, also is commemorated in some mosques. ${ }^{20}$ Namely in Djame Taibah mosque in Amsterdam. Those themes are a combination of fiqh (Islamic jurisprudence) and cultural tradition, usually adopted by certain communities. Some mosques in the Netherlands customize their jum'ah sermon materials with various traditional beliefs to strengthen Muslim community, their rituals and social relations. Following the improvement of knowledge pertaining to renowned themes, material for ritual lectures has been delivered to improve people's comprehension of details of rituals. In the end, preachers usually recommend Muslims to prioritize religious lives over temporal affairs.

One of the strategies used by mosques, as it is adopted by Djame Taibah mosque in (Amsterdam), is by telling excerpts of biography of the Prophet's companion, 'Umar b. al-Khațāb. Preacher in that mosque elaborated on the excellence of 'Umar b. al-Khattāb, who lived humbly because he prioritized what came after death. In addition, the preacher listed what is considered good and bad, the Do's and Don'ts from Islamic perspective.

Rightly so, since rituals are part of Islamic jurisprudence, it is apparent that Islamic jurisprudence becomes a major theme of lecture

\footnotetext{
20 Ashura is also important for Jews they celebrate it to commemorate the day God saved Noah from flood. For Muslims, especially Shiites, the Ashura is remembered as the day in which Husein was killed by Ummayyad soldiers.
} 
in the Netherlands' mosques. Muslims in the Netherlands seem to be very curious for further guidance on this aspect of Islam, the shari'ah. Moreover, because they are minority, material on $M u^{\prime}$ ámalab (Islamic jurisprudence governing the transaction of goods and service) becomes of utmost importance. It has to be informed to Muslims who visit mosques and to Muslim community at large.

Nevertheless, theme of rituals seems to have become the basis for development of an understanding of model of Islamic rituals. However, the mu'amalah theme seems to have become an advanced topic to fortify the social dynamics of Muslim lives. Both rituals and mu'amalah have adapted a distinct character of Dutch Muslims because of various European social factors or the lack of attention from local community.

\section{Politics of Religion}

Muslims are a minority in the Netherlands. It is a must that Muslims do something about their social lives, which is constructing mosques, which started as a small community but grew bigger over period of time. ${ }^{21}$ It is also apparent that the establishment of Islamic institutions has been a selective process, mosque is one of the become pillars. The existence of mosques in the country has intensified public debate in negotiating the utilization of public space-the case of establishment permission of mosques in Amsterdam and another place. ${ }^{22}$ The plan was initiated by Indonesian Muslim community, but it faced difficulty in obtaining permission from municipal authority because, as a secular country, the Netherlands does not recognize religious establishment. Therefore, although the permission was finally granted by local authority, it was under the name of Indonesian Culture center, not a mosque. Muslims keep using it as mosque.

This shows that the Dutch government still tolerates minority groups, although they consider religion as culture. They do not care about the function of the center as long as it is registered as a center, not a mosque. Mosques for Muslim minority groups in the

\footnotetext{
${ }^{21}$ James C. Kennedy and Jan P. Zwemer, "Religion in the Modern Netherlands and the Problems of Pluralism", The International Relevance of Dutch History, BMGN - Low Countries Historical Review, Vol. 125, No. 2-3 (January 2010), 237-268.

22 Jan Rath, Thijl Sunier, Astrid Meyer, "Islam in the Netherlands: The Establishment of Islamic Institutions in a Depolarizing Society", Tijdschrift voor Economische en Sociale Geografie/Journal of Economic and Social Geography, Vol. 88, No. 4 (1997), 389-395.
} 
Netherlands are significant not only because of their theological obligation but also their symbolic connotation (Metcal). ${ }^{23}$ The appearance of this place of worship becomes apparent in its new place because it becomes crowded with congregation who regularly attend for religious purposes. In its development, their tradition is adorned public space, which in turn triggers reaction from Dutch people.

Place of worship also acts as representation of certain races, ethnicity, religion, equality, and political empowerment. The attendance of certain ethnic minorities with distinct cultures (religion) to their place of worship has become center of attention for local Dutch community who consider religion as private matter, and it is always related to public policy. The well-established association or institution usually concerns pubic welfare. This religious meaning, as it happens with religious activities of Muslim minority in the Netherlands, needs to be included in city planning. It also means that the Netherlands' Muslim struggles for recognition have challenged the arrangements and understandings of the place of religion in society, especially mosque, as a center of religious activity. ${ }^{24}$ Although Indonesia, once a Dutch colony, its traces, especially mosques, are non-existent.

To build a mosque in the Netherlands need long and winding road since it requires intensive negotiation among Muslim community, local neighborhood who happen to be Dutch people, the Dutch authority, and the representative of country of origin of the Muslim community who to build a mosque in relation to ethnicity, scope (local or national), level of organizational networking, and its religious power. The analysis of this negotiation process in turn produces an understanding between countries, religion, and Muslim position in the form of possibility and impossibility, opportunity, and constraint in relation to integration. Its further impact is the realization of the plurality of nation, religion, tradition and how they perceive themselves in a country, the Netherlands.

\footnotetext{
23 Thijl Sunier, "Constructing Islam: Places of Worship and the Politics of Space in the Netherlands", Journal of Contemporary European Studies, Vol. 13. No. 3 (December 2005), 317-334.

${ }^{24}$ Cora Schuh, Marian Burchardt, Monika Wohlrab-Sahr, "Contested Secularities: Religious Minorities and Secular Progressivism in the Netherlands", Journal of Religion in Europe, Vol. 5, No. 3 (2012), 349-383.
} 
The integration process is not easy or not a neutral process because each uses their power to show power, its authority and power. The integration of Muslims into the Dutch society can be said as a group emancipation process, which is supported by organizations and institutions they created. Therefore, Islamic organizations can be said as collective action, even as power politics action. Their wellinstitutionalized cunningness as a tradition can run their function as Muslim social agents can take over the forum or people's discourse in dominant way.

Certainly, a Muslim agent strives for identity and identity tools (symbols) as Muslims in political process for their interest and the interest of Muslim community in the Netherlands at large. Although Muslims are minority, they are able to enter into a broader world with the identity of Muslims. This is proven in every issue that emerges, either in education, labor, housing, health, and welfare of migrants, Muslims always take part in discussion. This Muslim agent is liaison between Muslim community and the Dutch authority. However, in reality, the process of integration is not a smooth process, because Muslim migrants are not easily accepted by local Dutch people because of different traditions. Furthermore, the locals wish that Muslims leave their religion to ease the acceptance.

Among blatant examples is the aspect of education. There is local regulation that public schools funded by the Dutch government should not contradict the established values proposed by the government. Yet, the government presumes that mosques become hotbeds of terrorism. This is an over-generalizing and black and white view because there are two main streams of Muslims in the Netherlands; the Salafis and the Sunnis. The Salafis tend to understand the text literally with offensive words in its delivery. This is a certain contrast with their Sunni brothers. While the indictment of terrorism might resonate the Salafis to certain truth, but quite distant likeliness from the Sunnis. However, what is perceived by uninformed outsiders is that mosques become breeding ground for terrorism. They do not judge from peaceful and warm behavior of each congregation. Thus, public space is formed by principles of disparity.

In addition, the Dutch government also launched a program of "Islam pillarization" (verzuling, silencing) towards Muslim migrants 
with the objective of accommodating migrant Muslim groups. ${ }^{25}$ The program includes polarization strategy, consultation with representative of identity groups, funding for religious institutions and avoiding depoliticization. The Dutch people see this program as a failure because the strategy to deal with massive influx of migrants creates negative consequences. For instance, the wave of illegal migrants who initially visited their relatives in the country, then worked part-time with low fare to hide their trails to stay in the country. The number of this type of migrant is numerous. This is a dilemmatic issue; for business community, this means cheap labor, but for immigration agency, it is alarming.

In retain of this pillarization, Dutch politicians are steadfast in the view on this immigrant issue that Dutch people express their resentment towards culture and tradition of migrants. Thus, animosity toward migrants is growing. Thus, local authorities tend to ignore minor harassment toward Muslim women, tolerate ethnic pockets, and let the growth of parallel society. Radicalism, which is thought to breed in mosques, is dealt with contra-productive archaic measures (with the assumption of migrants with low-level education) by enacting policies and amendment of constitution to ease various institutional legacies of polarization. From the perspective of Dutch policy, the treatment of migrants with this polarization approach has successfully shown their cordiality and humanitarian attitude. Nevertheless, the implementation is sometimes subjective which compromises the result.

On the other hand, public policy and social processes need to get special attention, namely the issue of the migrant second generation who are born in the Netherlands. Some Indonesian Muslims in the Netherlands got married to local Dutch people, who eventually converted to Islam, and gave birth to children who are born in the country. The children are not exposed to Indonesian culture and confused in determining their traditions. Many of whom stated they are Dutch with Indonesian origin. They only know and live Dutch tradition, including the notion that at the age of majority, they are entitled to do whatever with their own life. They live separate lives from their parent and often earn money to support their lives.

25 Marcel Maussen, "Pillarization and Islam: Church-state Traditions and Muslim Claims for Recognition in the Netherlands", Comparative European Politics, Vol. 10, No. 3 (2012), 337-353. 
From the parents' point of view, who still linger with Indonesian religious culture, they feel in dismay. Especially they no longer have the right to intensively "educate" their children in this matter. This condition is a matter of culture, not the domain of government or authority.

In a secular state, the responsibility of religious education is at the hand of individuals, mainly parents. Therefore, when there is an opinion saying that Pillarization policy is unnecessary and will not succeed, it echoes some truth. In fact, the growth of Islamic institutions in from of mosques or Islamic study groups is in line with the dynamics of their social environment. The ever-growing religiosity among community in the Netherlands in the case of religious conversion does happen. The converts are attracted to the teaching of Islam they discover by themselves, less about the preaching done on its behalf. Therefore, it can be said that the preachers function as religious confirmation or habituation with the congregations, not calling for conversion. ${ }^{26}$

The development of Muslim in the Netherlands tends to focus on inter-ethnic religious activities, not cross-ethnic boundaries. This is reasonable because of each ethnic group responsible for the wellbeing of relatives and especially children. The mixture of ethnicity and religion is really a guarantee for the survival of religious convictions and traditions among children. Therefore, Muslim migrants, except for Indonesian Muslims, tend to find it difficult to assimilate with the Dutch people.

Thus, polarization is beneficial for Dutch government, especially with the mutual support of migrants for the government. Moreover, the government funds the schools run by Muslims; mosques, television stations, and so on. The accommodation policy of Islam, in the beginning, seemed to be a symptom of Islamization, but this assumption eased at the end. However, the Dutch people have different opinion on Muslims from Turkey, Morocco and Suriname in one side, and Muslims from Indonesia in the other. This is related to their ethnicity concerns, which is based on their interest. Indonesian Muslims are different in the sense that their Islamic activities often reach beyond an ethnic boundary.

\footnotetext{
${ }^{26}$ An interview with NISIS (Netherlands Interuniversity School for Islamic Studies) team in Yogyakarta, 13 August 2016.
} 
Muslims are a religious minority in the Netherlands. On the other hand, Islamic rituals and traditions cover all aspects of life; birth (should be born within an Islamic wedlock); marriage (using Islamic solemnization); rituals (should be performed in mosque); halal food (with Muslim butchers), halal income, and death (using Islamic funeral). The cycle of Muslim life is guided by Islamic teaching, but certainly it needs regulation or government policy for public issues. In this case, the Dutch government fulfills it through regulatory frameworks, namely Act on Democracy in 1988 and Act on Funeral in 1991.

Furthermore, the attention of the Dutch government on Muslim community is also reflected in education. Among the $70 \%$ of elementary and secondary education funded by the government are Islamic schools. The support also acts as a controlling mechanism towards the schools so that they provide education that supports the government. However, some observations found that Islamic schools were underperformed. This also needs addressing as the government wants to improve the quality of education of migrants who are mainly low-fare laborers with a low level of education.

\section{Concluding Remarks}

In general, lecture material in the Dutch mosques covers three aspects of basic Islamic teachings, that is aqidah (theology), shari'ah (Islamic law, including rituals and transaction), and akbläq (morality). Basically, the most delivered sermon materials are about aqidah and shari $a h$. Of the two topics, shari ${ }^{-6}$ h materials are also written for public consumption. Topics of aqidah are usually delivered in special events and within individual consultation. Conversion of local Dutch people to Islam usually a result of intensive and private discussion with Muslim scholars in mosques. Meanwhile, there are also regular study groups discussing aqidah. Some mosques affiliated with a number of schools should adapt their beliefs according to leadership of Muslim community who observe respective schools of law and theological persuasion. Traditionalist Sunni Muslims from Indonesia, Turkey, and Morocco embrace Ash'arite theology, whereas other sects such as Shīah, Ahmadiyah, Qor'ani, Salafi have their slightly different understanding of Islamic theology.

For instance, the Indonesian congregation of al-Ikhlas mosque in Amsterdam supplements their belief in the hereafter with its 
subtopics from Indonesian tradition, such as supplication for the deceased, tablil $d u^{\prime} a$, recitation of chapter Yāsin, istighäthah, et cetera. This topic is combined with important events in the Islamic calendar; that Muslims should allocate their time for this life and hereafter. On the other hand, mosques with Salafi congregation discuss a lot about the purification of Islamic creed and accuse unorthodoxy of tradition and belief which are not taught or practiced by the Prophet. They speak offensively against the practices of other mosques that do not meet their ideal.

Shariah is also a favorite topic for lecture and writing. Some preachers consider shariah relevant for the need of the Dutch Muslims on a daily basis. The preachers tend to deliver materials on rituals (fiqh) and social transactions (mu'amalah) as best they could to assist Muslims in determining good and bad in their lives. Akhlaq (ethics) is also frequently discussed in the mosques. However, it supplements other topics, such as mu'amalah, which is not in the Dutch context. In addition, lecture materials should also give substantial solutions for current affairs, namely the issue of Syrian refugees, negative stereotypes in media towards Islam, the good relationship between migrant Muslims and non-Muslim Dutch people. Sermon materials that tend to criticize Dutch tradition that upholds openness should be delivered in such a way to avoid controversy.

The profile of Muslim preachers can be Salafi and Sunni in the context of Islamic propagation in the Netherlands. They are experts in basic Islamic knowledge (Quranic exegesis, Prophet traditions, theology, jurisprudence, ethics, and so forth). They also ably adapt to the Dutch situation in the Netherlands. Moreover, preachers must be well versed in what Muslim youths experience and deal with their lives. They must have the ability to spread peace publicly. In addition, preachers also deliver their sermons in Dutch language for easy comprehension by local audiences. Thus, Islam in the Netherlands should be presented with a local touch. Nonetheless, although preachers play a significant role in representing Islam in the Netherlands, there are several instances that conversion to Islam starts with the converts' own independent study of Islam, marriage, or something illogical. They just consider Islam is a beauty and then choose to convert. 
The policy of the Dutch government on religion is a matter of controlling Muslim migrants. The government launched a policy called Islamic Pillarization, through several policies, namely the acknowledgment of religious activities, which acts as the liaison between the migrants and the government. Admittedly, this policy is somewhat unsuccessful because religious activities operate within the tradition of each country of origin. Likewise, government involvement in education by establishing and funding elementary and secondary schools still cannot improve students' performance.

\section{Bibliography}

Aziz, Moh. Ali. Ilmu Dakwah. Jakarta: Pranada Media, 2016.

Beaumont, Justin. "Candice Dias, Faith-Based Organisations and Urban Social Justice in The Netherlands", The Royal Dutch Geographical Society, KNAG, Vol. 99, No. 4, 2007.

FORUM. The Position of Muslim in the Netherlands. Utrecht: Postbus, 2010.

Ilaihi, Wahyu. Komunikasi Dakwah. Bandung: Rosdakarya, 2010.

Kennedy, James C. and Zwemer, Jan P. "Religion in the Modern Netherlands and the Problems of Pluralism", The International Relevance of Dutch History, BMGN - Low Countries Historical Review, Vol. 125, No. 2-3, January 2010.

Magazine, Alif. "Menikmati Perbedaan: Shalat Jumat di Belanda (1)", 22 January 2015/accessed on October $23^{\text {rd }} 2015$ from http://alifmagz.com/?p=29842

Maussen, Marcel. "Pillarization and Islam: Church-state Traditions and Muslim Claims for Recognition in the Netherlands", Comparative European Politics, Vol. 10, No. 3, 2012.

Meuleman, Johan. "Da'wa", Competition for Authority, and Development, Journal Bijdragen Tot De Taal-, Land- En Volkenkunde, Vol. 167, No. 2/3, 2011.

Poole, Elisabeth. Reporting Islam: The Media and Representation of Muslim in Britain. London: I.B. Tauris, 2002.

Rath, Jan. Against the Current: The Establishment of Islam in the Netherlands. Canada: Canadian Diversite, 2005.

Rath, Jan., Sunier, Thijl., Meyer, Astrid. "Islam in the Netherlands: The Establishment of Islamic Institutions in a Depolarizing Society", Tijdschrift voor Economische en Sociale Geografie/Journal of Economic and Social Geography, Vol. 88, No. 4, 1997. 
Richardson, John. Representing Islam: The Racism and Rethoric of British Broadsheet Newspaper. Amsterdam: John Benjamins Publishing Company, 2004.

Schuh, Cora., Burchardt, Marian., Wohlrab-Sahr, Monika. "Contested Secularities: Religious Minorities and Secular Progressivism in the Netherlands", Journal of Religion in Europe, Vol. 5, No. 3, 2012.

Sözeri, Semiha., Altinyelken, Hülya Kosar., Volman, Monique. "Training Imams in the Netherlands: The Failure of a Postsecular Endeavour," British Journal of Religious Education, June 2018.

Sunier, Thijl. "Constructing Islam: Places of Worship and the Politics of Space in the Netherlands", Journal of Contemporary European Studies, Vol. 13. No. 3, December 2005.

Sunier, Thijl. "Moslims in Nederland, Nederlandse Moslims: Sociale Integratie in de Sfeer van Religie" in G. Engbersen and R. Gabriëls (eds.), Sferen Van Integratie. Naar Een Gedifferentieerd Allochtonenbeleid. Amsterdam: Boom, 1995.

The interview result with Mr. Budi Santoso as senior official of Al Ikhlas mosque Amsterdam 18 October 2015.

Verkaaik, Oskar and Arab, Pooyan Tamimi. "Managing Mosques in the Netherlands Constitutional versus Culturalist Secularism", Journal of Muslims in Europe, Vol. 5, 2016.

Verkuyten, Maykel and Yildiz, Ali Aslan. "Muslim Immigrants and Religious Group Feelings: Self-identification and Attitudes among Sunni and Alevi Turkish-Dutch", Ethnic and Racial Studies, Vol. 32, No. 7, 2009.

An interview with Imam Hasanath on October $4^{\text {th }}$, 2015, at Roterdam.

An interview with NISIS (Netherlands Interuniversity School for Islamic Studies) team in Yogyakarta, 13 August 2016.

An interview with Suleyman Balkayan on October $10^{\text {th }}$, 2015 at Tilburg Mosque.

An interview with Thoar Varenkamp on October 16 ${ }^{\text {th }}, 2015$ at Amsterdam.

An observation at al-Ikhlas mosque, Amsterdam on October $9^{\text {st }} 2015$. An observation at El-Fath Moskee on October $21^{\text {st }} 2015$.

An observation at El-Tawheed Moskee on October 23 $3^{\text {rd }}, 2015$. 